\title{
機械部品および構造物の破損事故*
}

\author{
大内田
}

久**

\section{Failures of Machine Parts and Structures*}

\author{
by Hisashi Ohuchida**
}

\section{1.まえがき}

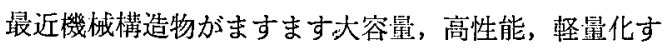
る傾向にしたがい，乙れらの設計に溶接構造を用いるこ とが多くなり，溶接部に働く使用応力もますます高く， 応力集中部で塑性变形の繰返しを伴う低サイクル疲れ や，合成化学工業の生成物の腐食や大気污染之いう特殊 の腐食環境下の使用など使用条件が苛酷になってきてい る.したがって今日では一層合理的な溶接設計と信頼度 の高い溶接施工が要望せられるわけである。しかしなが ら溶接構造物の破損事故例をしらべてみると，不測の過 大応力の発生, 連転操作の䛣りにもとづくあのもある が，な招設計者や溶接作業者の不注意に原因する事故も 多い. 製品の破損事故となると不名誉なととのため，じ ゆうらいからてれについての詳細な発表はきわめて少な い. そのなかで1956年より国際溶接会議（ＩＩＷ）が各 国に㧍ける溶接構造物の破塤例を集めて討議し，その結 果を機関誌の Welding in the World に発表している ことは敬服に值する。また渡辺》は溶接構造物にみられ た破壊例とその解析について明解な所見之設計者, 作業 者への指哼を与えており貴重なむのである. しかし前述 の I I W の事故例について屯采知の点で不じ方分で あり, その他の事故例の解説む少なく, 種々の機械部品 や構造物についての特徽ある事故例の解説が望まれる.

ここに大先䧳馬埸くめ夫博士の「改過為福」「失敗は 教訓の素」「臭いむのには蓋をするな」の落穂の教えに したがい，前述のI I Wで集めた破壊例の文献, Thielsh 著 Defect and Failures in Pressure Vessels and Piping やその他筆者の入手した交献や事例を参考しして, 機械構造物の破損事故についての解説を試み参帣供す ることとした。

\section{2. 破損の要因}

溶接された機珹部品や構造物の破損の要因を大別する

* 原稿受付 昭和 43 年 9 月 12 日

** IE 只 日立製作所 Member, Hitachi Research Laboratory, Hitachi Ltd.
と次の 4 つに帰せられるように思われる.

(1) 溶接設計の不良

(2) 工.作不良

(3) 材料不良

（4）使用条件の把挃不良

\section{1 溶接設計の不良}

（a）外力の見積りの誤り 機械部品に加わる外力の 大きさと種類に対する見積り違いから生ずる事故が今日 なお多い、乙れは応力，ひずみの測䇥技術が進歩した今 日でもな打機械構造物の実働荷重の測定が困難な場合が 多いととに起因している、特に地震, 突風, 鿉突, 水 盤, 共振などの過渡的現象によって生ずる過大荷重の見 積りは，過剩品質にならぬようにとの警成もあり困難な ところである。

（b）応力集中に対する配慮の欠如 形状の不連続部 に生ずる応力集中部に，溶接部が一致するとアンダカッ 卜や溶着鋮の形状, 治金的切欠きなどが重なり, 構造物 の複雑な 3 軸応力状態亡も影響し合って, 応力集中の見 皘りが困難となることがあり, 繰返し荷重の下で思わぬ 破損を起こすことがある。

（c）継手の設計不良機械部品や棈造物の使用荷重 の種類, 大きさ, 繰返し回数, 使用環境を考え, それら に芯じたじゅう分な強さの継手で，溶接欠陷の生じにく く，非破壊的欠陷㭘査がじゅう分行なえる形式のものを 選ぶべきである. 応力集中を生ずる融合不足, スラグ巻 込みなどの溶接欠陷を内蔵し，非破壊検査もできにくい 継手は使用を禁止すべきである、

（d）材料の選定不良 機械部品や構造物の使用条件 に適した溶接性のよい材料を選定すべきで，政量化によ る製品原伍低娍のため, 溶接性の悪くじ九性の低い高張 力鎆を使用するとか，溶接熱履歴によって脆化するもの の使用，また厚肉の多少次陷のある鋳鏉品に異種の鋼板 を溶接し複合構造にして使用するなどは戒しむべきであ る. ラミネーション偏析の多い材料は，その異方性のた めに荷重の負荷方向によっては思圾弤応力破壊を生ず ることがある。 
（e）溶接作業に対する考虑 溶接作業の難易によっ て溶接された機械部品の強さの信頼度が異なる. 溶接作 業が楽で欠陥や変形を生じないような継手予構造物の形 を選ぶべきである．また作業上応力除去焼なましのでき ない場合には, 残留応力による変形や強さにおよぼす影 響について設計時考虑しておく必要がある.

\section{2 工作不良}

現場において実際に機械部品や構造物を溶接する場 合, 溶接棒の管理, 溶接環境の管理が不良のため, 溶接 欠陷や大きな変形を生じ，乙れらが破損の原因となる. とくに本体は注意して丁寧に溶接を行なっても, その前 後に行なわれる仮付や付加物の溶接作業に対してはじゆ う分な配虑がなされなかったため，思わ好事故を生ずる ことあある. 軸類などで製作時の工作誤りや材質欠陥, 使用中に生じた摩耗のため, 局部的に肉盛りして溶接補 修する場合，予熱後熱の欠如に上る材質の硬化ぜい化を きたし，溶接欠陥を生じ破損の原因となるととも多い，

\section{3 材料不良}

設計の項でも述べたが，溶接性の悪い材料，ラミネー ション, サルファバンド, ブロホール, 非金属介在物の ある材料の使用は避くべきである。設計者が材料を指定 しても，検収や材料の保管の管理がよくないと不良材料 が知らぬ間に使用されていて破損の後の調査で分る例も ある，材料費節約のため，材料の引張強さを高めること に苦心し, 材料の溶接性, じん性を無視したため, 製造 時応力割れを生ずることがある.

\section{4 使用条件の把握}

機械や構造物の使用条件, 使用環境をじゆう分事前に 調査して製作することが大切である，実際には設計者が 考えも及ばなかったような荷重の種類や大きさ, 温度, 腐食環境に製品がさらされることがある。したがって事 前調查を極力行なって, 使用条件に適した溶接設計を行 ない, 屯っと屯適した材料の使用, 防食対策, 応力除去 烧なましなどの工作上の処置をしておくべきである，最 近化学工業, 発電所の増設により大気污染を生じ, この 腐食環境が機械的応力と組合されて疲れ強さが著しく低 下し機械が破損する例も生じてきている。

\section{3 . 破損例の現象的分類}

溶接された機械や構造物の破損例を破壊の現象別に分 類してみると次のように大別されるが，もっとも多いの が疲れ破壊である。

（1）疲れ破壊 高サイクル疲れ，低サイクル疲れ， 腐食疲れ, 熱疲れ, 高温疲れ

（2）ぜい性破壊

(3) 応力腐食
(4) クリープ破断

（5）遅机破壊

（6）水素ぜい化による破壊

以下各種の機械構造物の破損例を色々な破壊現象につ いて数例あげて解説してみたい.

\section{4. 破壊例}

\section{1 エンジンの摇腕の破損}

機械構造物の名称 : 高圧の空気を断熱膨脤させて低温 の空気をつくる膨脹エンジンの摇腕. 図一1のように力 ムからの上下動をロッドを介して排気弁に伝える，ロー ラ座の部分上摇腕の部分の二つがボルトで結合されその 上側面をスミ肉溶接で連結されている。応力状態：衝撃 的に加わる繰返し曲げ応力, スミ肉溶接し端部で最大 $12 \mathrm{~kg} / \mathrm{mm}^{2}$ の片振引張り応力, 繰返し数約 $1.6 \times 10^{6}$ 回. 破損状況 : 図一 2 のようにローラ座と摇腕のスミ肉溶接 部および摇腕上面に疲れき裂発生. 材料：SC 42 破損の 推定原因：ローラ座と摇腕の結合がボルト結合だけでは 不じゅう分なので側面スミ肉溶接をしたが, 摇腕の上面 角のスミ肉溶接端部にかえって応力集中を生じ, 溶接残

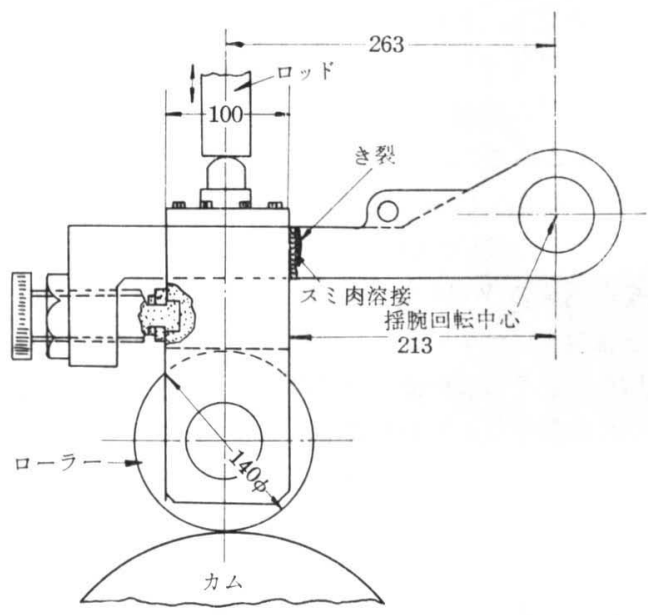

図一 1 膨脹エンジンの搯腕

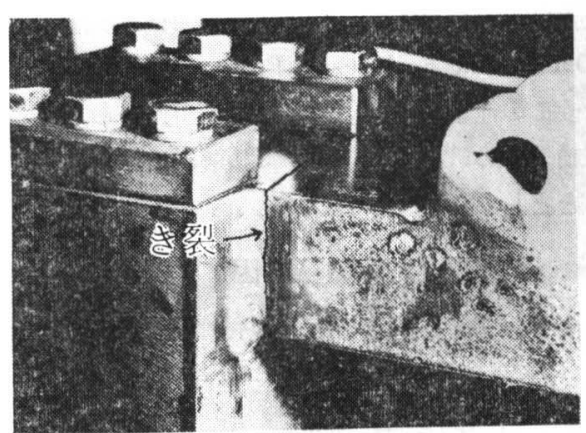

図一２摇腕溶接部の疲れき裂 
留応力の影響と組合されて疲れ破損した。 ローラ座と摇 腕を一体構造とし, 曲り部の曲率半径を $50 \mathrm{R}$ と大きく することによって最大応力を $4 \mathrm{~kg} / \mathrm{mm}^{2}$ に求さえるて とができた。

\section{2 フォークリフトのフォークの破損}

機械構造物の名称：フォークリフトのフォーク. 応力 状態: 繰返し曲げ応力, 悪路走行時にさらに付加応力が 働く, 使用時間 3,600 時間. 破損状況 : 図一 3 の上うに フォークの曲りの隅の溶接部に, 断面の約10\%に達する 疲れき裂が生じ後脆性破断した変形はみられない. 図一 4 の破面からわかるように内側の表面の多数箇所から疲

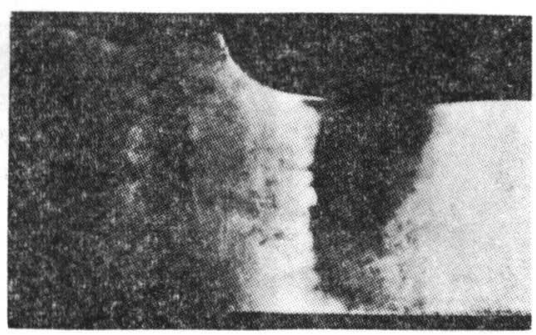

図一３フォーク隅部の破損

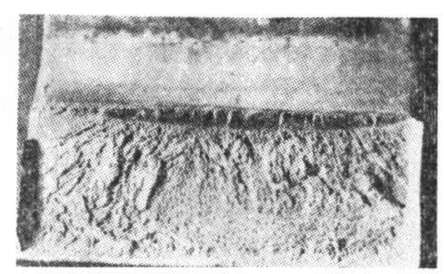

図一4 フォークの破面

れき裂が発生しており，乙れらはこの隅部にある溶接の し端部のアンダーカット部に相当する。前にも破損した ため, 溶接補修した。 その大きな溶接ビードの存在が破 損に関係した。材料：引張強さ $87 \mathrm{~kg} / \mathrm{mm}^{2}$ の炭素鋼. 推定原因：前にも破損し弱いととがわかっていたフォー クの応力の高い部分で溶接を行なった。 アンダカットの ある溶接の存在が疲れ強さを低下させた。 溶接補修して あ早晚破損が起こることが予想さるべきであった。. 非破 壊検査で使用中疲れき裂の発生を検査すべきであった。

\section{3 羽根付き軸の破損}

（1）曲げ荷重の場合. 機械構造物の名称：鐉造機用 電動機, $30 \mathrm{~kW}, 6$ P., 4 枚羽根. 応力状態: 回転曲げ応 力とねじり応力, 周期的に定格の $200 \%$ の過大応力が繰 返された. 稼僖後 1 年 8 个月で破損. 破損の状況：図一 5 のように羽根端溶接のし端部で疲れき裂が発生し, 図 一6のような同転曲状の破面を呈して破断している。最 終破断部が大きいてとからも過大応力が作用したととが
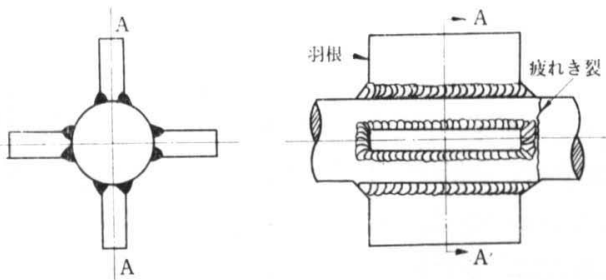

図一 5 羽根付き軸

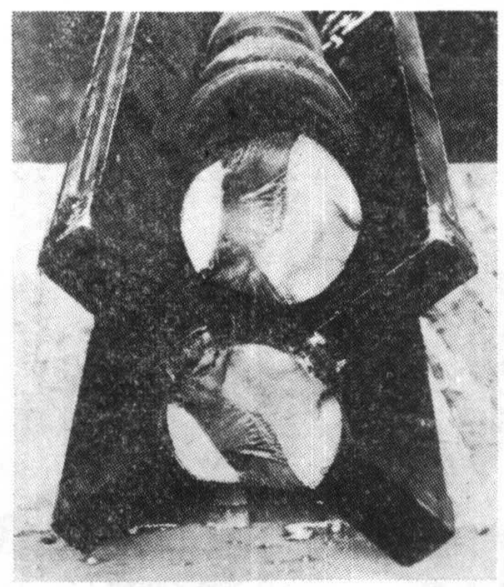

図一 6 羽根付き電動機軸の破面（回転曲げ）

わかる。材料：S 35 C. 破損の推定原因：定格の $200 \%$ の 過大応力がかかったとと, 端の溶接部の仕上げが不じゅ う分であったことが原因である。このような羽根端の溶 接では溶接線が短く, 溶接を羽根の周りに廻す運棒がむ つかしいため, この溶接部にブロホール, スラグ巻込, アンダーカットなどの溶接欠陥を生じやすく, 疲れ強さ 低下の原因となる。直径 $100 \mathrm{~mm} \phi$ の溶接のままの軸の 疲れ強さは約 $7 \mathrm{~kg} / \mathrm{mm}^{2}$ であるが, 機械仕上げ, ショ ットピーニングを行なうと約 $12 \mathrm{~kg} / \mathrm{mm}^{2}$ に疲れ強さが 向上する.

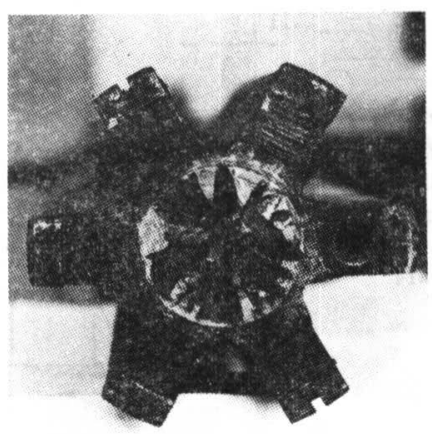

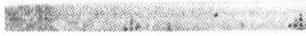

図一７羽根付き発電機蟿の破面（ねじり） 
（2）ねじりの場合. 機械構造物の名称：ディゼルエ ンヂンに連結された補助発電機. 応力状態 : ディゼルエ ンヂン軸との連結軸系のねじり共振により過大ねじり応 力材料: $\mathrm{S} 30 \mathrm{C}$, 引張強さ $52.6 \mathrm{~kg} / \mathrm{mm}^{2}$, ねじり疲れ限度 $14 \mathrm{~kg} / \mathrm{mm}^{2}$. 破損状況 : 図一 7 亿示すように軸の外周多 数箇所から中心に向ってひだが生じているが，ねじり繰 返し応力により疲れき裂が外周数箇所より発生, 破面が 食い違って生じたひだである．破損の推定原因：軸系の ねじり共振により過大応力が生じ, 羽根端の溶接部が軸 のフイレット部の応力集中にあったとと, 溶接部の仕上 げがじゆう分でなかったてとがあげられる.

\section{4 フランヂとパイプの結合部の破損}

機械構造物の名称：エンヂンの排気管とフランジ，応

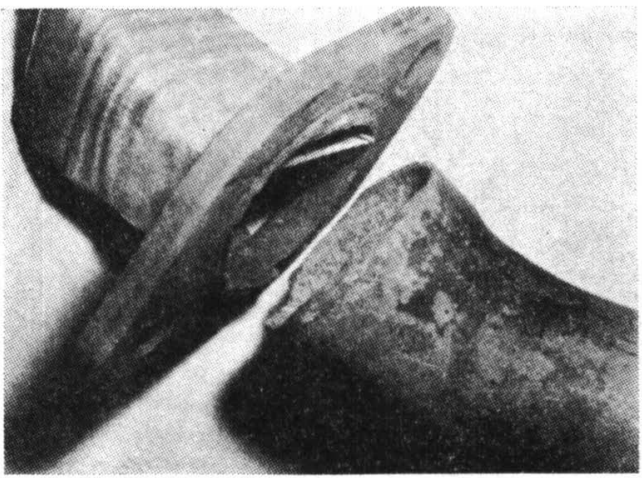

図一８エンジンの排気管の破損

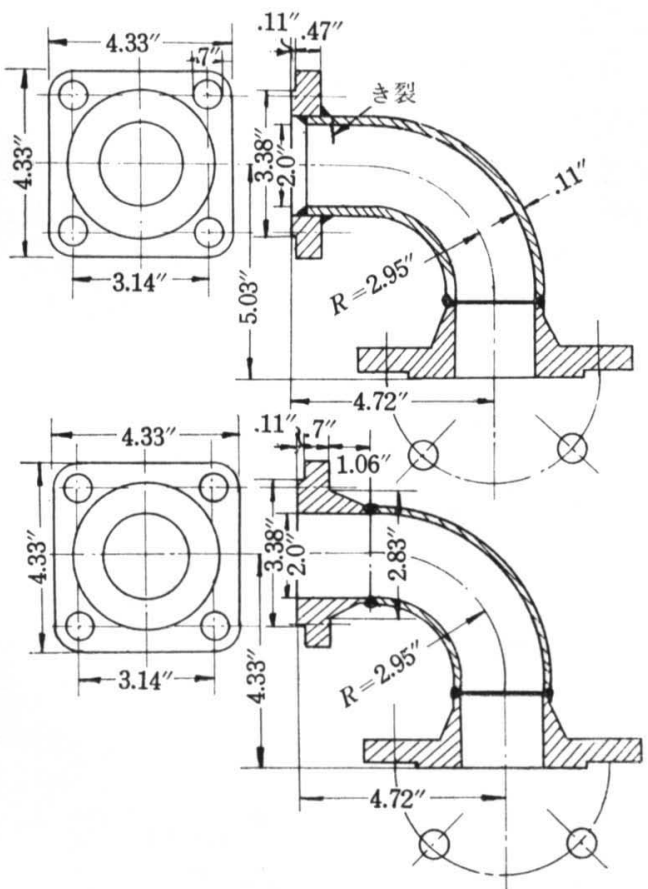

図一 9 フランヂとパイプの溶接結合
力状態 : エンヂンからの振動による曲げ応力および熱応 力の繰返し 破損の状況 : 図-8 からわかるようにフラ ンヂとパイプの溶接結合部で疲れ破損をしている。図一 9 の上図は同様な例で空気圧樎機に用いられたパイプと フランヂの結合であるが，350時間使用後に図の位置に 疲れき裂を生じた. 破損の推定原因 : パイプをフランヂ の内側にはめ込んで溶接した構造のものでは，断面の急 変による溶接部の応力集中と振動応力, 熱応力の重複に よって破損した．図ー9 の下のようにフランヂにテーパ をつけ突合せ溶接し，パイプを可撓的にしたものは強度 上好ましいあのとして推奨できる.

\section{5 パイプの補強リブの破損}

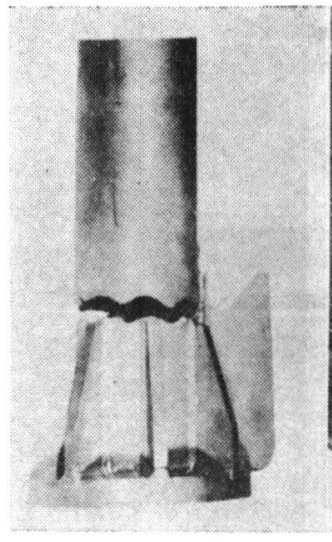

(a)

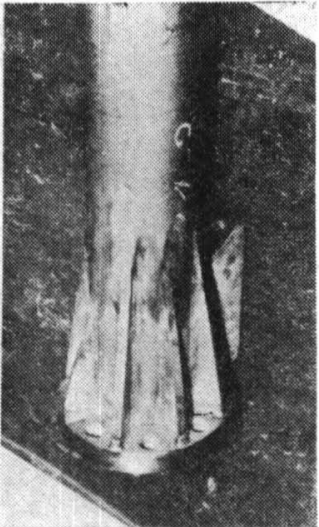

(b)
図一10 補強リブのあるパイプとフランヂ結合部の破損

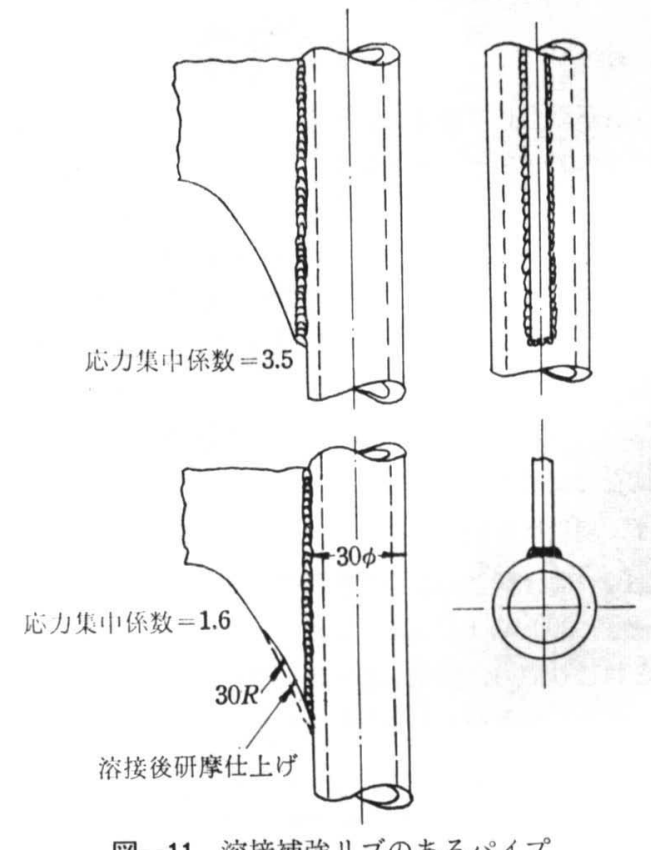

図一11 溶接補強リブのあるパイプ 
機械構造物の名称：パイプ 応力状態：過大な機械的 繰返し応力と熱応力. 材料: 17-4 pH 不銹銅 破損の 状況 : 図一10(a)のようにパイプとフランヂを補強リプ で結合したリプの端部のパイプ部で破損. 破面はぢぐざ ぐしており過大応力による破損であるととがわかる．破 損の推定原因：補強リブとパイプの溶接部の断面急変に よる大きな応力集中と過大応力が原因. 図の（b ）のよ うに補強リブのテーパを小さくし、リブ端の溶接部を滑 らかに仕上げれば強さが改善される. 図一11のように補 強リブの端の形および仕上げに注意すれば応力集中係数 が3.5から1.6に減少し疲れ寿命が70\%伸びる.

\section{6 ノズル部の破損}

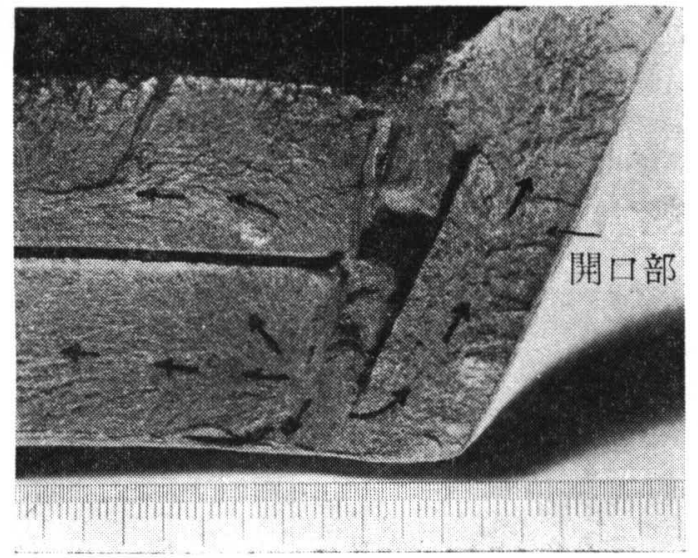

図一12 圧力容器ノズル部の破損（ぜい性破壊）

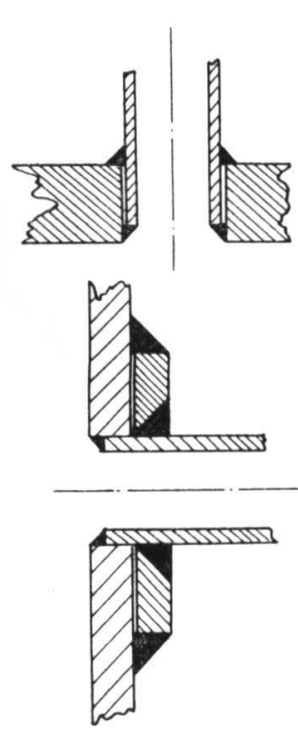

(a) 不良
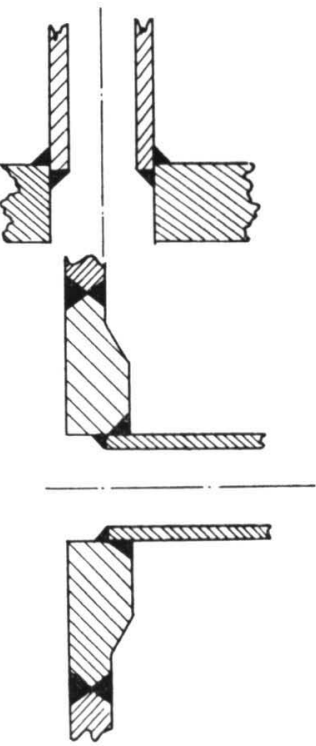

(b) 良
図一13 熱疲れを受ける場合のノズル部の補強
機械構造物の名称 : 圧力容器のノズル 応力状態 : 内 圧による膜応力および熱応力, 13年間使用, 内圧繰返し 1700回. 破損の状況：図一-12に示すようにノズル補強板 の溶接不完全な応力集中部よりぜい性破壊している.

材料：SB 41 破損の推定原因：低温における過大内 圧上昇による過大応力上溶接設計の不良による応力集中 によるあのと思利れる. 図一13のように熱疲れも考えら れるような場合には（a）のような補強でなく（b）の ようにするととが望ましい。

\section{7 ロックゲイト歯車軸の破損}

機械構造物の名称：ロックゲイトの歯車 応力状態： 回転曲げ応力, 繰返し数 50,000 回, 3 年間使用 破損状 況：図一14に示すようにロックゲイトを動かす車輪と軸

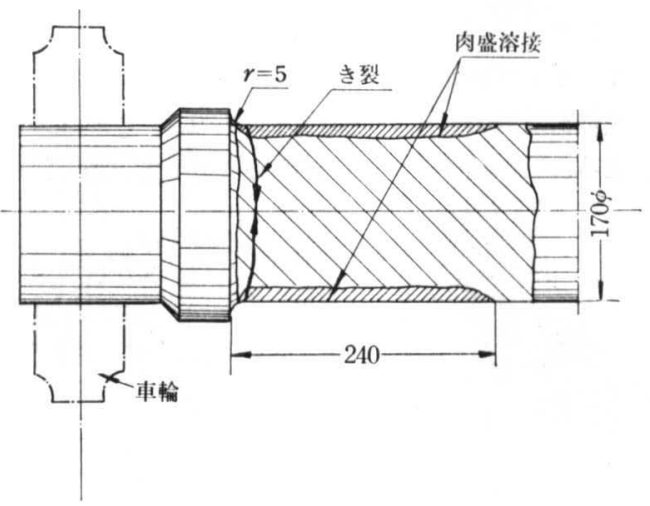

図一14 ロックゲイト歯車軸の破損

受の中間のフイレットと肉盛溶接端とが一致した部分よ り疲れき裂が発生している。 この部分は常に海水に浸清 されていた。軸受部の軸の部分が摩耗したため, 肉盛 溶接を行ない，その後応力除去なましがしてあった，材 料：引張強さ $40 \sim 50 \mathrm{~kg} / \mathrm{mm}^{2}$ 炭素鋼. 破損の推定原因 : 破損は応力集中の著しい筒所に肉盛溶接を行なったこ とに原因する。しかしなかには車輪から $30 \mathrm{~cm}$ あ離れ た軸の角柱の部分でき裂が入った場合もあり，てれは溶 着鋼の端にあたる，乙のととから溶接はじゆう分満足す べきものであったにもかかわらず操作に問題があったの ではないかと思われる，とにかく応力集中や腐食環境の ある場合の肉盛は著しく疲れ強さを低下させることに注 意すべきである.

\section{8 溶接肉盛または補修軸の破損}

最近工作不良や使用中の摩耗のために軸受部分や回転 軸のカップリングやその他の部材がはめ合される部分に 肉盛溶接が溶接設計, 溶接作業や軸の材質の検討をよく しないで不用意に用いられ，肉盛後機械仕上げをして体 裁をよくして使用されることがあるが, 数ヶ月あるいは $1 \sim 2$ 年を出ないで溶接部やその近くから疲れき裂が発 


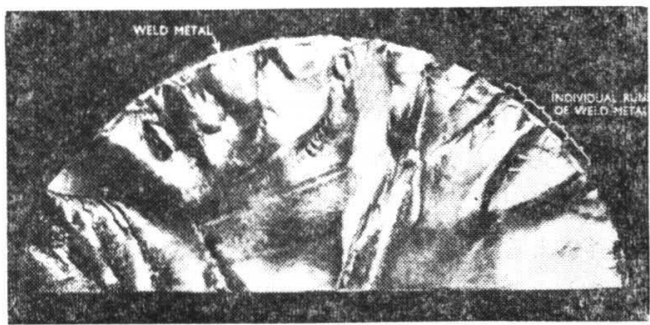

図一15 溶接補修軸の破面

生して軸が破損する例が多い，図一15に典型的破面の一 例を示す，乙れは溶接補修して再使用後35時間経過して 破損している。溶接肉盛軸の場合は溶着鋼の数箇所加ら き裂を生じて，乙れらが連らなって破面に多数のひだを 生じているのが特徴である. 以下に溶接補修によって生 じた実際の破損の数例を示す.

\section{9 ポンプ軸の破損}

機械構造物の名称：垂直ポンプ, $80^{\circ} \mathrm{C}$ で $98 \%$ の硫酸 を送る. 図一16の上はポンプの配置を示す，応力状態：
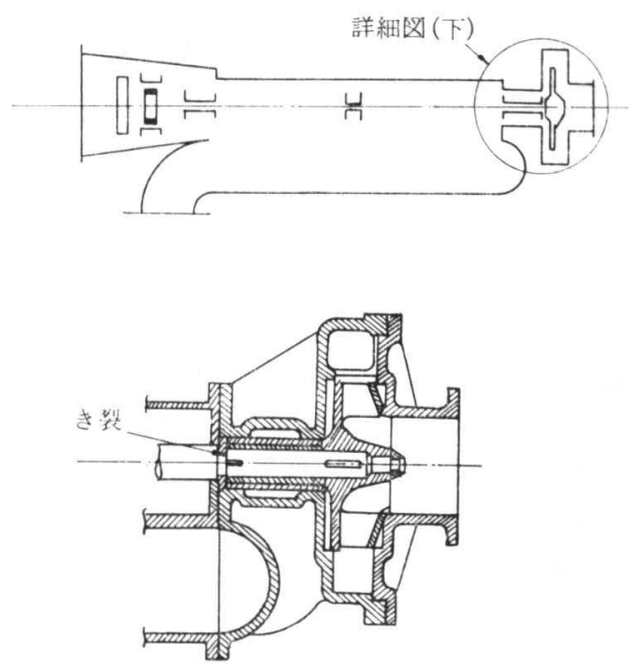

図一16 垂直ポンプ軸の破損

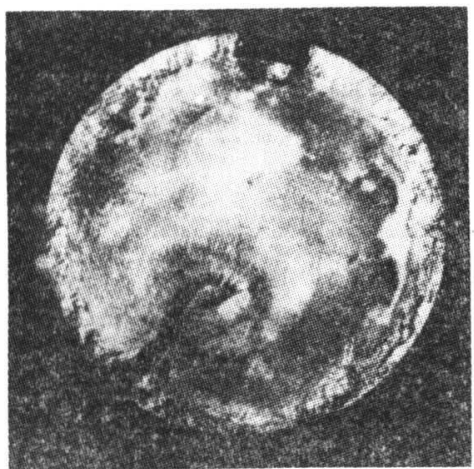

図一17 ポンプ軸の破面
足常状態では札じり応力がかかるが，同時に軸受の組立 不良や軸の振動によってはポンプを支持している端部に 曲げ応力が生ずる. 繰返し応力は曲げによるもので回転 曲げとなる. 応力繰返し回数やポンプの回転速度不明.

材料：不銹鋼, Cr 18, Ni 11, Mo 2, Ti $2 \%$, 引張強 さ $60 \sim 75 \mathrm{~kg} / \mathrm{mm}^{2}$. 破損の状況 : 図一17に示すようにキ 一みぞを通って軸は破損し, ポンプの最初の軸受の入口 で断面変化部から少し離れた䈉所. 外周の溶接金属部の 粗粒状破面の部分を除いては平滑な細粒状の疲れ破面を している。き裂発生の最初の部分はキーみぞ部である。 破面からも回転曲げを受けて破損したてとがわかる．推 定原因：破損は明らかに溶接補修によって生じている. キーみぞ部にみられる溶融不足からみてあ補修がじゆう 分な注意をむって行なわれたとは思われない.

\section{0 エアドロップハンマーのアンビルの破損}

機械構造物の名称：エアドロップハンマー, 容量 $3 \mathrm{t}$, 車輛用部品の型打鋸造機, 困一18にその概略形状を示 す.

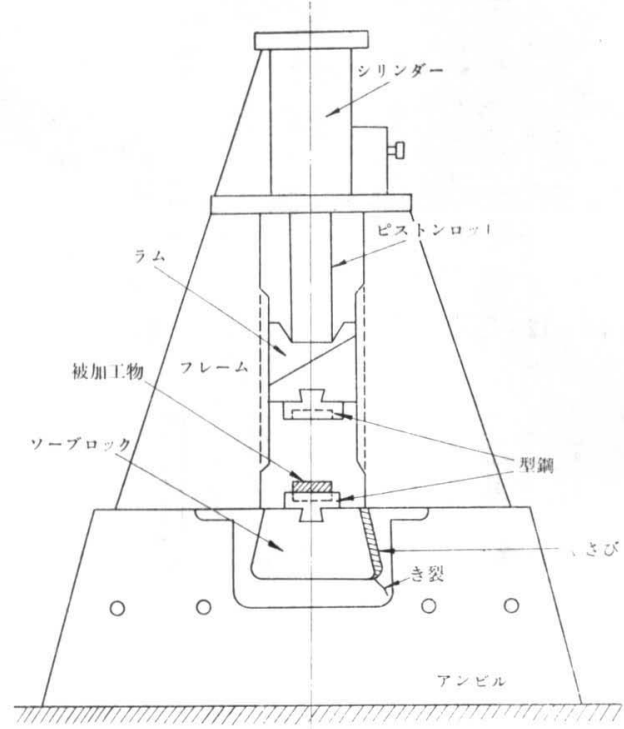

図一18エアドロップハンマーのアンビル

応力の種類扰よび使用履歴：型打ちによりアンビルの 隅部には繰返し曲壮の衙撃応力が働く。その大きさは $10 \sim 15 \mathrm{~kg} / \mathrm{mm}^{2}$. 使用後1.5年でアンビル隅部の材料欠陥 （いぐるみ）よりき裂発生，乙れを溶接補修した．開先 の作成は酸素了セチレンバーナによりき裂発生部を流 し，後グラインダにて整型した。忉料：SC 46, 引張強 さ $49.4 \mathrm{~kg} / \mathrm{mm}^{2}$, 衝撃值 (Vノッチシャルピー) $7.6 \mathrm{~kg}$ • $\mathrm{m} / \mathrm{cm}^{2}\left(20^{\circ} \mathrm{C}\right), \mathrm{LB}-26$ 溶接棒を使用して于溶接にて溶 按し，応力除去焼なましは行なわずピーニングをじゅう 分行ない, 後手仕上げを行なった。佊損の状況：図に示 
すように再びアンビール隅部に深さ $60 \mathrm{~mm}$ のき裂を発 生した. 推定原因 : すり合せ不良のためくさびが片当り して隅部に型鉣造時過大応力が生じたととと, 溶接補修 時開先をとるためアセチレンバーナーで局部加熱し, 溶 接燒なましを行なわずピーニングではじゆう分とれない 残留応力が残っていたためと思われる。

\section{1 クランク軸の破損}

機械構造物の名称: 深海トロール船の 6 シリンダ $1,350 \mathrm{HP}$ エンジンのクランク軸. クランクピンにあけら れた $20 \mathrm{~mm} \phi$ の油孔が図一19(a) のようにあけるべき を外側表面から内側表面まで(b)のように貫通してあけ られてしまった。 それで内側の開口部はねじをきって栓 をして塞ぎその頭を溶接した. 応力状態 : クランクピン はねじりと繰返し曲げ応力を受ける。応力振巾不明．エ ンジンの回転数 165 r.p.m, 破損まで 70,000時間運転され ていた。破損の状況：クランクピンを横切り直角に破壞 がクランクピンの半周にわたり生じている. 図一20から わかるように疲れき裂がねじのせん溶接の頭の周りを二 つにわかれ用むようにして進んでいる. 図一21のピンの

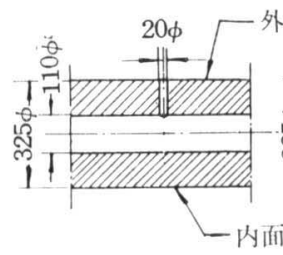

(a)

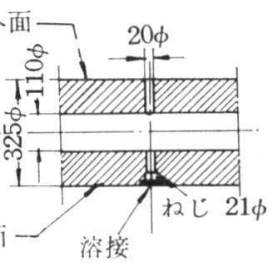

(b)
図一19 クランクピンに開けられた穴の詳細

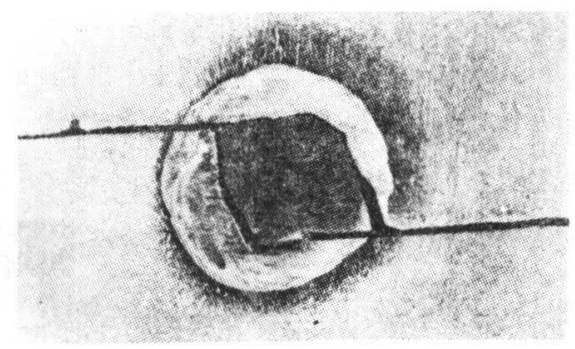

図一20 せん溶接された外表面の部分に生じた疲れき裂

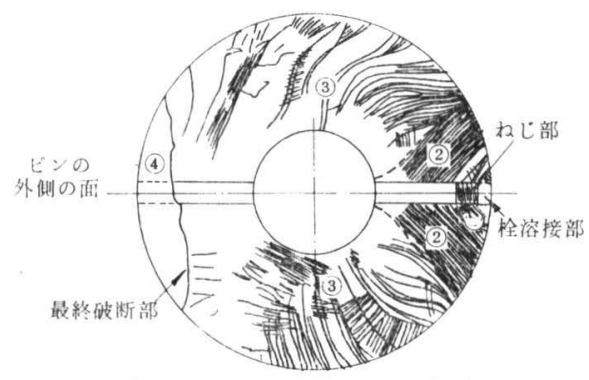

図一21 クランクピンの破面
较面からわかるように破壊は繰这し応力によって進んで おり, 最終佊断部はクランクピンの外面近くであり, 詳 細にみる上破面は1)，(2)，(3)，(4)の4 つの部分から成っ ている。(2)の部分は目が細かくき裂の進んだ軌跡は直線 状である，佊壊はDの部分で発生しているが，穴を塞い だ溶接部の下より発達した脆い分離破面を呈している. これは溶接時の収縮き裂によって発生したものと思われ る. 航海中にせん溶接部よりぜい性破壊が生ずるような 突発事件はなんら報告されていない, 材料 : S $25 \mathrm{C}$, 引 張強さ $47 \mathrm{~kg} / \mathrm{mm}^{2}, \mathrm{U}$ ノッチシャルピー值 $2.2 \sim 3 \mathrm{~kg}$ • $\mathrm{m} / \mathrm{cm}^{2}\left(0^{\circ} \mathrm{C}\right)$ 破損の推定原因：工作の誤りで油孔をク ランクピンの内側の外面まで貫通させたので，ねじをき ってせん溶接をした．その溶接箇所の材料が多数の硫化 物介在物を含んでいたため, 収縮き裂を生じ, これから 絽返し荷重により疲れ破壊が進んだものと思われる.

\section{2 プロペラ軸の破損}

機械構造物の名称：トロール船のプロペラ軸, 直径 $135 \mathrm{~mm} \phi$, 長さ $4.83 \mathrm{~m}$ 全長にわたり表面に不銹鋼が溶 射されている. 2 ストローク，6シリンダ $42 \mathrm{P}$ のエン ジンに 1 段減速で連結されている，応力状態：エンジン からプロペラへ伝達するトルクによるねじり応力と回 転部分の重量による回転曲げ応力. エンジンの回転数 375 r.p.m シャフトの破損まで 20,000 時間使用破損の 状況 : プロペラのはめられているテーパ部に, 図一22の

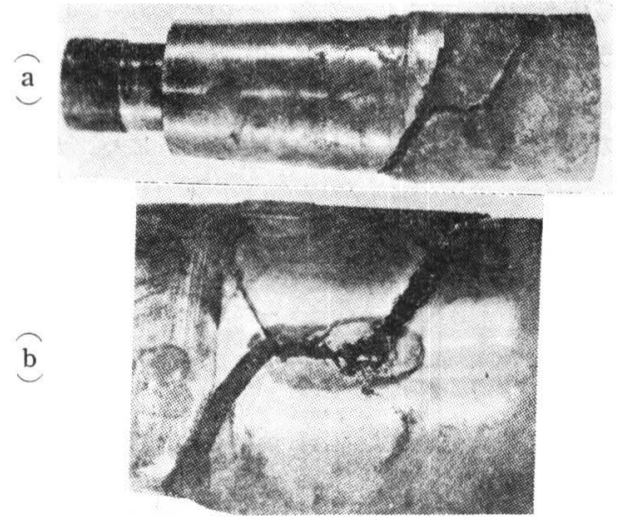

図一22 プロペラ軸の破損の外観

ように斜めのき裂が生じその軸方向となす角度は $55^{\circ} \mathrm{C}$ である，中央の軸方向き裂の長さは $40 \mathrm{~mm}$ で，その破 面は多孔性で局部的にスケールが付いている. 図一23か らわかるように明らか疲机破面を呈している。Aの部 分は㣙の厚さの半分をしめており, $\mathrm{A}$ と $\mathrm{A}^{\prime}$ の境より 疲れき裂が発達している，Aの部分ではき裂が軸方向に 走っている. 材料：引張強さ $46 \mathrm{~kg} / \mathrm{mm}^{2}$. 破損部分を腐 食してみると図一 $22(\mathrm{~b})$ の上うに補修溶接部が発見され 
最終破断部

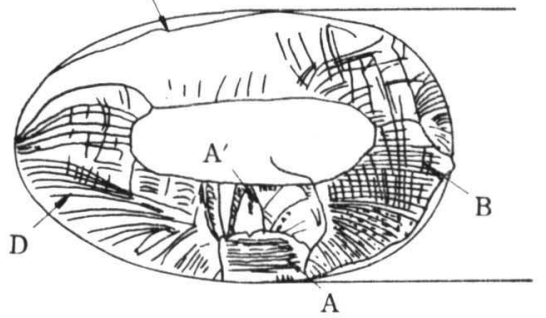

図一23プロペラ軸の破面

た. 破損箇所以外にもテーパ部表面に数ヶ所補修が行な われていたととがわかる。溶接条件不明 推定原因：主 な原因は軸の材料の選定が悪かったととで，軸方向き裂 の部分にパイプや偏析などの材料欠陥があった．とのよ うな材料欠宿部を溶接した。材料が表面からかなりの深 さまで不健全であったので，実際の溶接では変形を生じ 軸方向の収縮き裂を生じたが，溶接後の機械仕上げでて のき裂が見えなくなっていた，ての重大なき裂が絽返し 対じり曲げ応力の下に疲れき裂の進展の源となった，き 裂の進行にともない，偏析のためき裂面にピッチング腐 食を生じた。このように不健全な鋸造材を最初に完全に 欠陥部分を除去しないで, 溶接によって補修することが いかに危険なものであるかを警告するよい事故例であ る.

\section{3 ケーブルカーのハンガーの破損}

機械構造物の名称：ケーブルカーのハンガー 図 -24 のように均合重鍾でバランスさせて乗客の乗る船室を吊 っているもの. 応力状態 : 船室の重さによる引張応力 破損の状況：破損は図一-25からわかるようにハンガーの

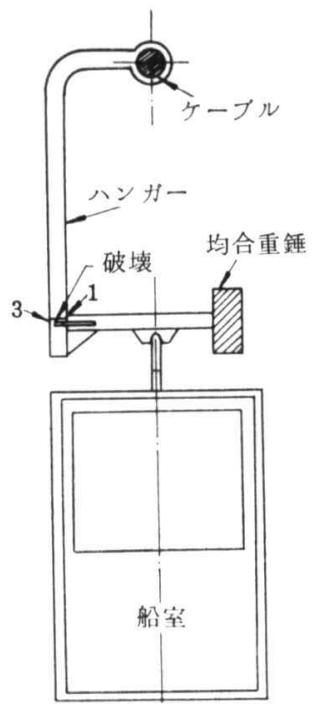

図一24 ケープルカー

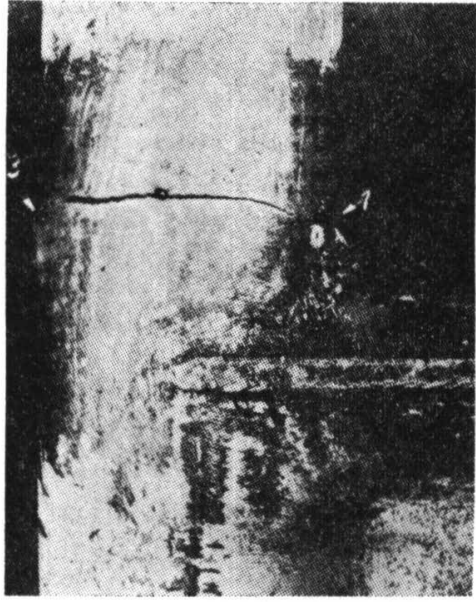

図一25 ハンガー破損部溶接趾端 1 よりき裂発生

垂直管之水平腕との溶接接合部の溶着鋼のし端から発生 した疲れ破壊である。破面は疲机破面の部分は小さくぜ い性破面の部分の面積が大きい. 材料：C $0.09 \%$ 炭素 鋼. $45^{\circ} \mathrm{V}$ /ッチシャルピー值 $0.8 \mathrm{~kg} \cdot \mathrm{m} / \mathrm{cm}^{2}\left(20^{\circ} \mathrm{C}\right)$ 破壊の発生点である端部の溶接はアーク溶接で, 不幸に 屯水平腕からの負荷を伝える溶接部にクレータや溶接再 開始のつなぎの場所が重なって存在していた, 破損の推 定原因：疲れ破壊の発生にはクレータや溶接のつなぎ場 所が原因しており，大切な応力集中筒所に溶接をもって きた溶接設計にあ原因がある. またパイプ材の材質があ ろかったととが疲れき裂がわずかに進行して全断面が完 全破壊する原因にもなった。

\section{4 リンクチェンの破損}

機械構造物の名称 : $1 \mathrm{t}$ 用モートルブロック用リンク チエン, $8 \mathrm{~mm} \phi$. 応力状態: 荷重の吊上げ吊下げによる 引張応力および曲げ応力の繰返し．との例は実際の事故

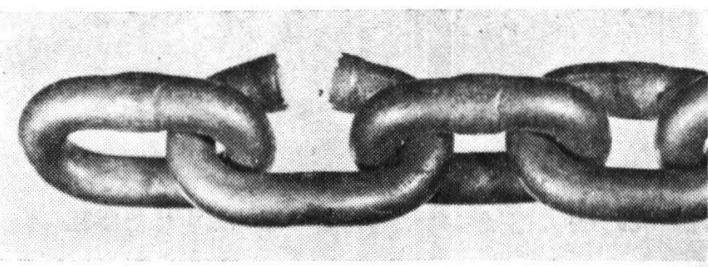

（a）溶接部破断

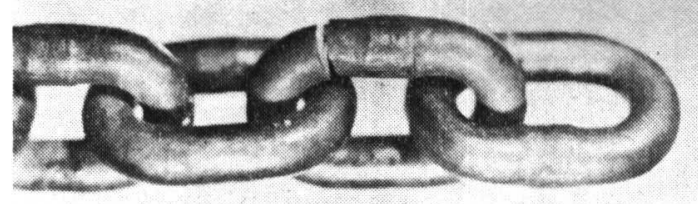

(b) 肩部破断

図一26 リンクチエンの破損 


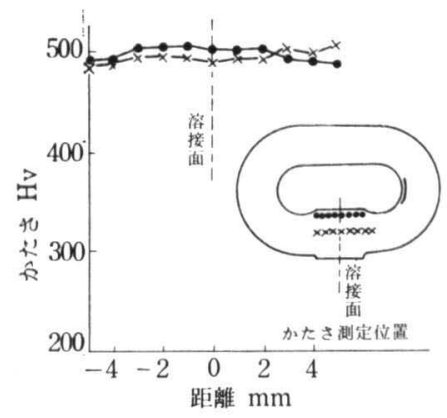

(a ）肩部で破断したもの

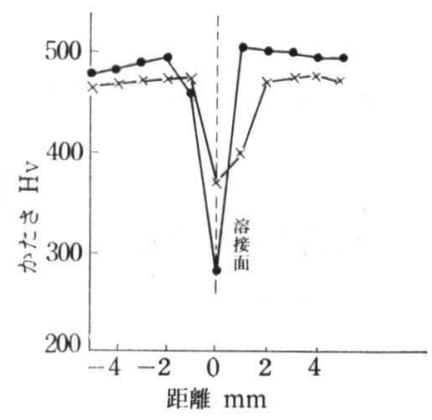

（b）溶接部で破断したあの

図一27 リンクチエンのかたさ分布

例ではないが破損の原因が参考になるので，その試験結 果について述べる. 荷重 $1.3 \mathrm{t}$, 寿命 $10^{5}$ 回が要求される. 破損状況：試験により破損したリンクチエンを図一26に 示す.（a ）はフラッシュバット溶接部で，（b）は肩部で 破断し, 前者は $10^{6}$ 回の繰返し数で破断荷重 $1.4 \mathrm{t}$, 後者 は $1.9 \mathrm{t}$ であった．破断付近のかたさ分布をしらべた結 果は図一27のように，肩部で破断したものは溶接部のか たさは一様であるが, 溶接部で破断したあのは溶接部の 突合せ溶接部で著しくかたさの低下がみられる，またて の部をマクロエッチしてみた組織から溶接部で脱炭がみ られた。材料：低 Mn 鋼, C $0.2 \sim 0.25 \%, \mathrm{Mn} 1.10 \sim$ $1.40 \%$ フラッシュバッド溶接後高周波焼むどし. 推定 原因：強さの低下したものはフラッシュバッド溶接時過 電流が流れ溶接部の脱炭を生じ, 局部的に強さの弱い部 分ができ,そのため疲㺈さが低下した。

\section{5 圧力容器の破損}

機械構造物の名称: 液体窒素の蓄冷器, 内径 1,800 $\mathrm{mm}$, 長さ $7,000 \mathrm{~mm}$, 板厚 $12 \mathrm{~mm}$. 応力状態: 常用内圧 $5 \mathrm{~kg} / \mathrm{cm}^{2}$, 下部鏡板付近 $-175^{\circ} \mathrm{C}$, 内圧は $0 \sim 5 \mathrm{~kg} / \mathrm{m}$. $\mathrm{cm}^{2}$ と 10 年間に約 $3.5 \times 10^{4}$ 回の繰返される. 破壊の出発 点之なった図一28の下部鏡のマンホールの開口部周縁の 最大応力は測定の結果約 $15 \mathrm{~kg} / \mathrm{mm}^{2}$ に達するととがわ

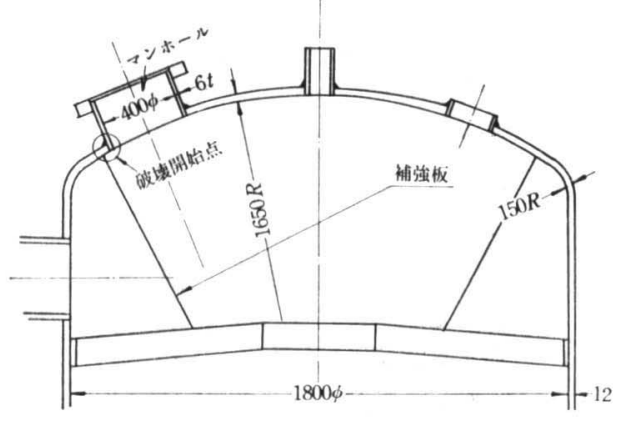

図一28 容器の下部鏡板
かった. 破損の状況: 空気が容器内に流入し $5 \mathrm{~kg} / \mathrm{cm}^{2}$ に達してから 30 分後に大きな異音を発して破壊した。 図 -28のマンホールの開口部で, 内部の補強板の取付部の 溶接部より破壊したものと思われる. ぜい性破壊. 破壊 開始点に疲れき裂が存在していたかどうかは確かでな い. 図一29(b) 亿破壊出発点附近の破面を示す. 材料： C $0.16 \%$ SS 41 キルド鋼, 引張強さ $40 \mathrm{~kg} / \mathrm{mm}^{2}, 45^{\circ}$ $\mathrm{V}$ ノッチシャルピー值 $6.0 \mathrm{~kg} \cdot \mathrm{m} / \mathrm{cm}^{2}\left(20^{\circ} \mathrm{C}\right)$ 破損の推 定原因：マンホール取付けの溶接と補強板付根の溶接が 重なり, 内圧により複雑な 3 軸応力となり大きな溶接残 留応力を生じ, 応力除去焼なましによりこれがじゅう分 除去されていなかった.

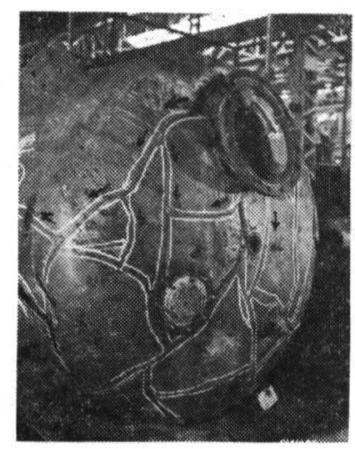

（a）破壊した下部鏡板

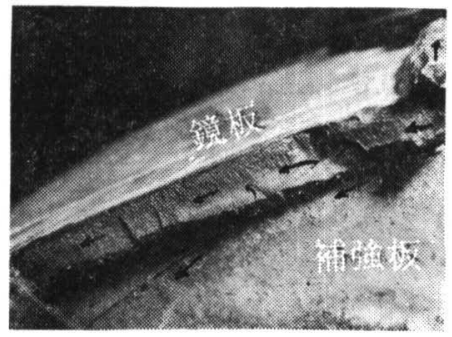

（b）破壊開始点と思われるマンホール付根と 補強板の溶接の重なった箇所

図一29 容器の損破状況 
疲れき裂の存在は確認できなかったが, 内圧の繰返し により, マンホール開口の周縁で補強板付根附近に微細 な疲れき裂が発生し，ぜい性破壊へと移行したあのと思 われる。

このような低温で内圧の繰返しがあり, かなり応力の 高い压力容器では, 応力集中や溶接欠宿の存在のある部 分を不銹鋼でつくり, 微細な疲れき裂が発生してあただ ちにぜい性破壊へ移行しない工夫が必要である.

\section{6 ボイラドラムの破損}

機械構造物の名称：ボイラドラム, 内径 $1,524 \mathrm{~mm}$, 長 さ $14.640 \mathrm{~m}$, 円筒部分の板厚 $111 \mathrm{~mm}$, 鏡板の板厚 90 $\mathrm{mm}$, 常用圧力 $147 \mathrm{~kg} / \mathrm{cm}^{2}$. 応力状態: 水圧試験圧力 204 $\mathrm{kg} / \mathrm{cm}^{2}$ のとき円筒部分の膜応力 $15.4 \mathrm{~kg} / \mathrm{mm}^{2}$, 鏡 板で $8.86 \mathrm{~kg} / \mathrm{mm}^{2}$ マンホールの開口縁 $\mathrm{A}$ 点の切線方向応力 $30.5 \mathrm{k} / \mathrm{mm}^{2}, \mathrm{C}$ 点で $16.4 \mathrm{~kg} / \mathrm{mm}^{2}$. 破損状況：破壊は $204 \mathrm{~kg} / \mathrm{cm}^{2}$ (最大使用圧力の1.4倍) の水圧試験時に生 じた. 水温約 $5^{\circ} \mathrm{C}$. 破壊以前に異常音や変わった状態は みとめられなかった，破壊は図一30に示すようにマンホ

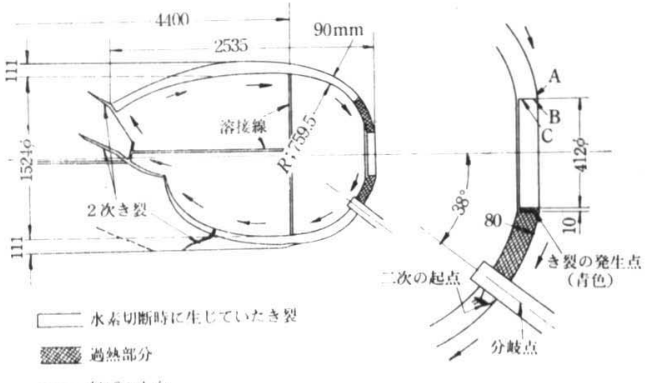

図一30 ボイラドラムの破壊状況

一ルの縁より発生し, 破面は水平に対し $45^{\circ}$ の傾きをむ って矢印のように進展している。破壊はほとんど変形な しに生じ, 破面はせん維状の脆性破面である。き裂の発 生したマンホール縁では巾 $10 \mathrm{~mm}$ の部分が青味がかっ た色をしている. 材料 : C 0.25, Mn 1.45 1.55, Cr 0.3, $\mathrm{Ni} 0.2, \mathrm{Si} 0.2, \mathrm{~S} 0.035, \mathrm{P} 0.025 \%$, 引張強さ $54 \sim 63$ $\mathrm{kg} / \mathrm{mm}^{2}$, 伸び $17 \%$ ，U ノッチシャルピー衝撃値 $4 \mathrm{~kg}$. $\mathrm{m} / \mathrm{cm}^{2}\left(20^{\circ} \mathrm{C}\right)$. 材料の組織に異常はみとめないが, 鏡 板の破壊開始点では過熱により生じた異常なセル粗粒組 織が発見された。そこでての過熱組織の屯のと正常組織 のものについてVノッチシャルピー試験を行なったとて ろ, 図一 31 に示すようにせん移温度の相異がみられ, 過 熱組織のほうがせん移温度が高いことがわかった. 工作 : 鏡板は熱間鋸造焼なましして供給された。マンホール は板を $150^{\circ} \mathrm{C}$ に局部的に予熱して酸素切断によってつ くられた. その後マンホール部は, 切断による熱影響部 を除去するために機械加工された．切断により局部加熱

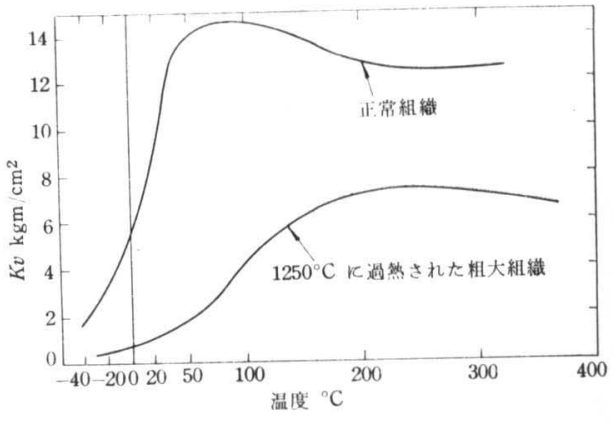

図一 31 シャルピーVノッチ衝撃值と温度の関係

された温度は組織加らて $1,250^{\circ} \mathrm{C}$ と推定され, 材料 試験はこの温度に過熱したものにつき行なった. ドラム の溶接組立後は $635^{\circ} \mathrm{C}, 8$ 時間の応力除去焼なましを行 なった。破損の推定原因：（1）ドラムの鏡板の材料 が熱間成形時に過熱されてもろくなった（2）乙のあ ろくなった鋼においてマンホールの酸素切断が行なわ れ，熱応力の影響で切断面に垂直方向のき裂を生じた.

（３）乙れらのき裂の伝ばがあろくなった金属に生じ, 応力除去されていたにもかかわらず水压試験で健全な鋼 板のほうへ伝ぱした。

\section{7 高圧給水加熱器の破損}

機械構造物の名称: 高圧給水加熱器, 水室の板厚 229 $\mathrm{mm}$, 内径 $460 \mathrm{~mm} \phi$ のノズル 2 個が図一 32 のように対 称の位置に溶接されている。水室の部分は円筒部に溶接 され $530^{\circ} \mathrm{C}$ に応力除去焼なましされた. 水室は仕切り

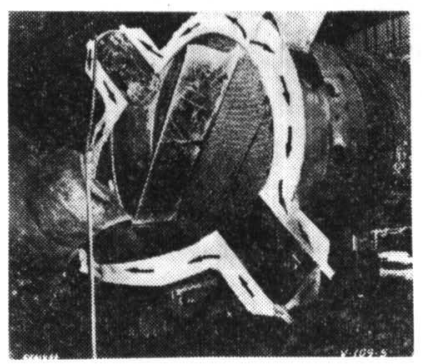

（a） 円筒部分の方を見た図

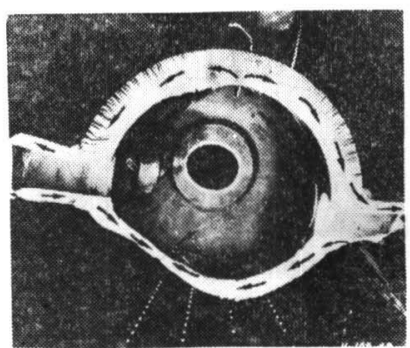

（b）鏡板の部分を見た図 図一32 高圧給水加圧器の破損 
溶 接学会誌

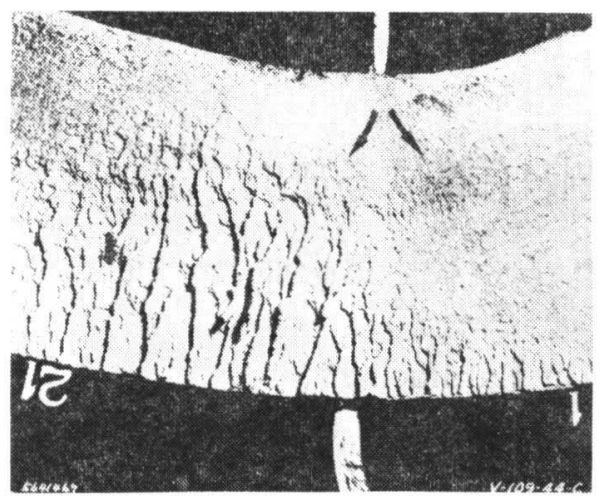

図一33 仕切り板を水室壁に溶接したととろからの 破壊状況

板で二つに分割されている，破損の状況：水圧試験時に ぜい性破壊した。破壊時の水圧 $371 \mathrm{~kg} / \mathrm{cm}^{2}$ 破壊は予告 なしに爆発的に生じた。図一-32の（a)，（b）は破壊時 の水室の状況を示す，矢印は破壊の進行状況を示す，材 料: ASTM 266-2, C 0.31, Mn 0.69, Si 0.18, S 0.022, P $0.005, \mathrm{~V} 0.041 \%$, 引張強さ $\sim 4 \mathrm{~kg} / \mathrm{mm}^{2}$, 伸び $31 \%$, $\mathrm{V}$ ノッチシャルピー衝撃值 $1.6 \mathrm{~kg} \cdot \mathrm{m}\left(20^{\circ} \mathrm{C}\right)$ 破損の推 定原因：（1）鍍造材のせん移温度が高かった.（2）仕 切板を水室壁に溶接したところ（図一-33）の熱影響部が ぜい化していた。（3）き裂発生部の高い 3 軸応力が材 料が局部的にひずみ応力を緩和する能力を著しく低下さ せた。

\section{8 不銹鋼円筒の破損}

機械構造物の名称：门简形貯槽, 図一 34 亿示すように パイプが挿入される部分の貯槽の壁が補強板で溶接補強 されている構造. 眝槽は $\mathrm{H}_{2}, \mathrm{CO}, \mathrm{CO}_{2}, \mathrm{H}_{2} \mathrm{~S}$ の圧力のか かった湿りガスを眝蔵する. 温度 $400 \sim 450^{\circ} \mathrm{C}$, 压力 15 $\mathrm{kg} / \mathrm{cm}^{2}$. 応力状態 : 主な応力は静的なものであるが, 機 械的振動がパイプに生ずると溶接部や補強板に動的応力 が生ずる。約 3 年間使用。破損の状況：き裂は補強板を 眝槽に溶接した溶接のし端部に相当する位置の槽の内面 から発生した. 図一34のように同時に $6 \mathrm{~mm}$ の脚長を 屯った補強板端のスミ肉溶接部からも発生した。 疲れき 裂は生として槽の内面より生じており, 内部の腐食媒質 によって誘起されている. 図一35は槽の板部からとった 顕微鏡写真で槽の内面から生じた多数の腐食疲れき裂を 示す. 材料：Ti で安定化した 18-8 不銹鋼. 破損の推定 原因：まづ設計時に予知できなかった不明の振巾をむっ た動的応力が疲れき裂発生の原因の一つで, 他の一つ は, 補强板のスミ肉溶接が断面の急変と “hard spot” をつくった，さらに腐食が疲れき裂発生の有力な原因で ある.

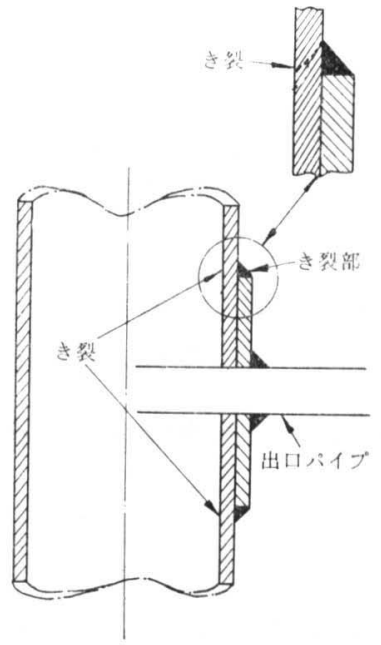

図一34 貯槽補強溶接部の破損

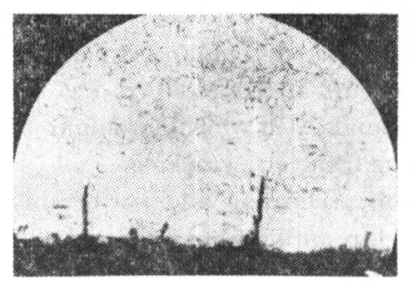

図一35 貯槽内面の腐食疲れき裂

\section{5. 結言}

機械の部品や構造物の溶接部の破損の要因および代表 的破損の数例につき述べたが，破損例については詳練な データが不明で, 破損の原因についてああい味なあのが あり読者は不満に感ぜられることと思うが, 溶接部材の 破損がどういう箇所にどのような原因で起とっており， 設計製作上注意すべき点は何かについて少しでも御参考 になれば幸いと存ずる次第である。なおまえがきに述べ たようにこれらの破損例は I I Wその他の交献より採用 したものであるが，破損という性質上出所を明確にでき ないことについては扔許しを願いたい．前記のI I Wの 事故例についてあその出所は不明にしてある.

これらの溶接破損例を参考にして再び同様な事故を繰 返すことなく, 最適の溶接設計, 最良の材料, 慎重な溶 接工作条件の下に高性能で軽量な溶接構造ができ, 今日 の急速なる技術革新に呼応できることを期待してやまな い.

文献

1）渡辺：機械の研究, 16, 1 (1964) 8/10, 16, 2 (1964) 278/284, 16. 3 (1964) $377 / 380$ 